\title{
Simulated response of an acid forest soil to acid deposition and mitigation measures
}

\author{
J. J. M. VAN GRINSVEN ${ }^{1 *}$, J. KROS ${ }^{2}$, N. VAN BREEMEN 1 , W. H. VAN \\ RIEMSDIJK ${ }^{2} \&$ E. VAN EEK ${ }^{2}$
}

1 Department of Soil Science and Geology, Wageningen Agricultural University, P.O. Box 37, NL 6700 AA Wageningen, Netherlands

2 Department of Soil Science and Plant Nutrition, Wageningen Agricultural University, P.O. Box 8005, NL 6700 EC Wageningen, Netherlands

Received 13 January 1989; accepted 11 May 1989

\begin{abstract}
A modified version of the soil-water acidification model ILWAS was applied to an acid forest soil in the 'Hackfort' experimental forest in the Netherlands. Monthly observations of the chemistry of atmospheric and soil water were available between April 1981 and April 1987. ILWAS overestimated water uptake reduction, which caused overestimation of soil water fluxes by $20 \%$, as compared to values predicted by the hydrologic model SWATRE. ILWAS does not simulate capillary rise which may lead to overestimation of solute concentrations. Chemical calibration of the ILWAS model to field data was mainly confined to adjustment of the rate constants for nitrification and gibbsite dissolution. Calibration of these rate constants was complicated by effects of cation exchange. ILWAS appeared to be too crude to simulate the $\mathrm{N}$-dynamics, which lead to a relatively strong variation of simulated $\left[\mathrm{NO}_{3}\right]$ near the end of the growing season. After calibration the ILWAS model was used to predict the effects of $50 \%$ reduction of $\left(\mathrm{NH}_{4}\right)_{2} \mathrm{SO}_{4}$ deposition, of a fertilization experiment with 2.6 $\mathrm{kmol}_{\mathrm{c}}$ ha- ${ }^{-1} \mathrm{~K}_{2} \mathrm{SO}_{4}$ and $8.6 \mathrm{kmol}_{\mathrm{c}} \mathrm{ha}^{-1} \mathrm{MgSO}_{4}$, and of removal of the forest vegetation.
\end{abstract}

Keywords: acid deposition, forest, soil acidification, simulation model, aluminum, scenario analysis, nutrient cycling, nitrification

\section{Introduction}

Acid atmospheric deposition is an important contribution to soil acidification (van Breemen et al., 1984). Mathematical models can be useful to improve our understanding of relevant processes and mechanisms, or to make predictions of soil acidification (Reuss et al., 1986). Available soil acidification models generally are integral parts of watershed acidification models (Christophersen \& Wright, 1981;

* Present address: National Dutch Institute of Public Health and Environmental Protection, P.O. Box 1, NL 3720 BA Bilthoven, Netherlands. 
Goldstein et al., 1984; Cosby et al., 1985a). Most recently developed soil acidification models are process-oriented models. Available models show a wide variation with respect to the number of distinguished processes, to the degree of simplification of process formulations, and to the degree of spatial and temporal discretization. Arp (1983) and Booty (1984) lumped all weathering reactions into Freundlich- and Langmuir-type isotherms, respectively. Bloom \& Grigal (1985) extended the empirical approach by Arp (1983), including pH-dependent mineral weathering of base cations, and empirical relationships between $\mathrm{pH}$ and $\mathrm{Al}$-activity in solution, and $\mathrm{pH}$ and base saturation. The soil acidification module in the RAINS model (Alcamo et al., 1987) compares the acid loading to the sequence of buffer systems proposed by Ulrich (1983); in case of acid soils and with decreasing $\mathrm{pH}$, base cation weathering from silicates is followed by cation exchange below pH 5, and below pH 4.2 also by dissolution of Al. Soil solution $\mathrm{pH}$ is calculated either as function of base saturation $(4.2>\mathrm{pH}>3)$ or in equilibrium with gibbsite $(\mathrm{pH}<3)$. The Trickle-Down model (Schnoor et al., 1984) is based on solution of the alkalinity balance for the watershed and surface water, and lumps all buffer processes in the soil into mineral weathering, at a rate depending on acid loading. Soil acidification models by Christophersen \& Wright (1981), Goldstein et al. (1984), Reuss \& Johnson (1985), Cosby et al. (1985a), van Grinsven et al. (1987a) and de Vries (1987) are based on explicit formulations of the key soil processes, and mathematical solution is obtained by solving the charge balance. Key soil processes may include $\mathrm{CO}_{2^{-}}$ equilibria, cation exchange, mineral weathering, anion sorption, gibbsite equilibrium, complexation reactions, nitrification, denitrification, nutrient uptake by plants, decay of organic matter and a water balance. The BIRKENES-model by Christophersen \& Wright (1981), the model by Reuss \& Johnson (1985), and the MAGIC model by Cosby et al. (1985a) enforce equilibrium with gibbsite. However, gibbsite equilibrium is not common in acid surface soils or in situations with high acid loadings (Mulder et al., 1987; van Grinsven et al., 1987a). The ILWAS model (Goldstein et al., 1984) allows rate-limited dissolution of gibbsite, and only enforces instantaneous gibbsite equilibrium at occurrence of supersaturation. The ILWAS model is the most comprehensive acidification model to date.

Although the final purpose of all referenced models is response analysis of soilwater systems to variable acid loadings, there is a great variation in the degree of discretization in time and space. All models are one-dimensional, but overland flow and sub-surface lateral saturated flow are considered in the BIRKENES and ILWAS model. The size of time steps varies between less than one day (ILWAS) and one year (RAINS model, Alcamo et al., 1987; Bloom \& Grigal, 1985). The MAGIC model lumps the soil profile to one compartment, while eg. ILWAS distinguishes genetic soil horizons. The RAINS model considers homogeneous grid areas of several thousand $\mathrm{km}^{2}$, while the model by Bloom \& Grigal (1985) is applied for specific soil columns.

The simulation models RAINS, BIRKENES, MAGIC and ILWAS have been subjected to sensitivity analysis, and were used to reconstruct acidification history (Cosby et al., 1985b) or to evaluate the response of catchments to changed acid loadings. Sensitivity analysis of the RAINS model showed particular sensitivity to initial 
base saturation, soil thickness and rates of silicate weathering. Scenario analyses with both the RAINS and the MAGIC model suggested that the $\mathrm{pH}$ and base saturation of soil will respond very slowly to reduced levels of atmospheric deposition of $\mathrm{SO}_{4}$. Analysis of the response of two watersheds by the ILWAS model (Fendick \& Goldstein, 1986) gave no indication of a threshold response to $\mathrm{SO}_{4}$ loading, but instead gave continuous response curves. For loading with $\mathrm{NO}_{3}$ a threshold response was observed, as a result of an upper limit for the uptake capabilities of the biota.

This paper describes the calibration of a modified version of the ILWAS model on an acid forest soil, followed by analysis of the response of this soil to reduced deposition of $\left(\mathrm{NH}_{4}\right)_{2} \mathrm{SO}_{4}$, to application of readily soluble $\mathrm{K}_{2} \mathrm{SO}_{4}$ and $\mathrm{MgSO}_{4}$ and to removal of the forest vegetation.

\section{Materials and methods}

\section{Modification of the ILWAS model}

The ILWAS (Integrated Lake Watershed Acidification Study) model was originally developed to predict acidification of surface water in the USA and Canada. Model formulations and principles of operation are given by EPRI (1983), Goldstein et al. (1984) and van Grinsven (1988). Soil water transport is simulated by a sequence of overflowing containers. Root water uptake is reduced below a critical water content. With respect to soil chemistry, soil compartments are considered as continuously stirred reactors. Solutes are transported by means of convection only. Most reaction rates are described by first-order kinetics. In the vegetation a leaf and a wood component are distinguished with a fixed chemical composition. Growth of the vegetation is controlled by a relative growth coefficient and its derivative with time. The monthly distribution of litterfall and nutrient uptake are fixed.

To simulate soil acidification processes in a Dutch acid forest soil the ILWAS model was modified on several points:

(1) The exchange of $\mathrm{Al}$ was included as $\mathrm{Al}$ is a major exchangeable ion in Dutch acid forest soils (Mulder et al., 1987). Modelling Al exchange necessitated replacement of the original Gapon-like exchange equations by more general GainesThomas-type exchange equations (Gaines \& Thomas, 1953). The general formulation for Gaines-Thomas exchange, with $\mathrm{Ca}$ as reference ion is:

$$
\begin{aligned}
& \mathrm{nCa}^{2+}+2 \mathrm{X}_{\mathrm{a}}=\mathrm{nCa}_{\mathrm{a}}+2 \mathrm{X}^{\mathrm{n}+} \\
& \mathrm{K}_{\mathrm{Ca}, \mathrm{x}}=\frac{\mathrm{ECa}^{\mathrm{n}}\left(\mathrm{X}^{\mathrm{n}+}\right)^{2}}{\left(\mathrm{Ca}^{2}\right)^{\mathrm{n}} \mathrm{EX}_{\mathrm{a}}{ }^{2}}
\end{aligned}
$$

where $\mathrm{K}_{\mathrm{Ca}, \mathrm{x}}$ is the selectivity coefficient, $\left(\mathrm{Ca}^{2+}\right)$ and $\left(\mathrm{X}^{\mathrm{n}+}\right)$ are solution activities (mol 1-1, and $\mathrm{ECa}_{\mathrm{a}}$ and $\mathrm{EX}_{\mathrm{a}}$ are adsorbed concentrations (equivalent fractions).

(2) Free drainage from the bottom soil compartment was included in the model. The original ILWAS version assumes an impervious bottom soil compartment, and simulates lateral groundwater flow to generate discharge. Dutch forest soils are 


\section{J. J. M. VAN GRINSVEN ET AL.}

mostly sandy and free drainage is a more convenient lower boundary condition for soil water flow.

(3) Furthermore, the simulation of canopy processes in the model, generating dry atmopheric deposition, leaf exudation and interception evaporation, and potential transpiration, was bypassed. Instead, the model was modified, to make more efficient use of the available input data from the catchment monitoring program.

\section{Site characteristics and model parameterization}

The soil is an Umbric Dystrochrept covered by a mixture of Quercus robur and Betula pendula. Chemical inputs and soil solution chemistry of the Umbric Dystrochrept have been monitored since 1981, at monthly intervals. Monitoring was ended in 1987. Details on soil characteristics and field monitoring are given by van Breemen et al. (1986, 1987, 1988). Physical and chemical model parameters are given in Table 1. Chemical inputs and solute fluxes are given in Table 2.

Table 1. Physical and chemical model parameters of the forest-soil system at the Hackfort estate.

\begin{tabular}{|c|c|c|c|c|c|}
\hline & \multicolumn{5}{|l|}{ Soil layer } \\
\hline & 1 & 2 & 3 & 4 & 5 \\
\hline Thickness (cm) & 5 & 10 & 10 & 20 & 60 \\
\hline Field capacity (vol \% water) & 30 & 33 & 28 & 24 & 11 \\
\hline Saturation (vol $\%$ water) & 80 & 65 & 62 & 57 & 41 \\
\hline Water uptake fraction $(\%)$ & 5 & 15 & 15 & 30 & 35 \\
\hline Nutrient uptake fraction $(\%)$ & 30 & 15 & 15 & 20 & 20 \\
\hline $\mathrm{N}$-uptake fraction $(\%)$ & 50 & 15 & 5 & 10 & 10 \\
\hline $\mathrm{CEC}\left(\mathrm{mmol}_{\mathrm{c}} \mathrm{kg}^{-1}\right)$ & 50 & 8 & 2.8 & 2.0 & 1.0 \\
\hline \multicolumn{6}{|l|}{ Exchangeable fractions (\%) } \\
\hline $\mathbf{H}$ & 26 & 52 & 50 & 52 & 49 \\
\hline $\mathrm{NH}_{4}$ & 32 & 1 & 0 & 0 & 0 \\
\hline $\mathrm{K}$ & 4 & 3 & 1 & 1 & 1 \\
\hline $\mathrm{Na}$ & 1 & 0 & 0 & 0 & 0 \\
\hline $\mathrm{Ca}$ & 16 & 8 & 2 & 1 & 2 \\
\hline $\mathrm{Mg}$ & 9 & 3 & 0 & 0 & 1 \\
\hline $\mathrm{Al}$ & 12 & 33 & 46 & 46 & 47 \\
\hline \multicolumn{6}{|c|}{ Gaines-Thomas exchange coefficients with $\mathrm{Ca}$ as reference ion } \\
\hline $\mathrm{H}(\mathrm{mol} \mathrm{l}-1)$ & $1.3 \times 10^{4}$ & $2.1 \times 10^{3}$ & $1.5 \times 10^{4}$ & $1.5 \times 10^{5}$ & $3.1 \times 10^{5}$ \\
\hline $\mathrm{NH}_{4}(\mathrm{~mol} \mathrm{l}-1)$ & 89 & 1000 & 1000 & 1000 & 1000 \\
\hline $\mathrm{K}(\mathrm{mol} \mathrm{l}-1)$ & 17 & 15 & 27 & 1.7 & 1.0 \\
\hline $\mathrm{Na}(\operatorname{mol~1-1)}$ & 12 & 0.53 & 3.8 & 1.9 & 4.0 \\
\hline $\mathrm{Mg}(-)$ & 1.2 & 0.61 & 0.46 & 0.31 & 0.36 \\
\hline $\mathrm{Al}(\mathrm{l} \mathrm{mol}-1)$ & 0.056 & 0.045 & 16 & 2.8 & 3.2 \\
\hline
\end{tabular}


Mineral fractions (\%)

$\begin{array}{llllll}\text { Microline } & 0.80 & 4.4 & 4.7 & 6.0 & 6.5 \\ \text { Albite } & 0.88 & 4.6 & 5.1 & 5.6 & 5.1 \\ \text { Pseudo Ca-Mg silicate } & 0.25 & 1.4 & 1.4 & 1.4 & 0.9 \\ \mathrm{Al}(\mathrm{OH})_{3} & 0.07 & 0.4 & 0.7 & 0.8 & 0.2\end{array}$

Parameters independent of soil depth

Pseudo first-order $k\left(10.5 \cdot \mathrm{mol}^{-0.5} \cdot \mathrm{yr}^{-1}\right)$

- microline, albite $\quad 0.01$

- pseudo Ca-Mg silicate $\quad 0.04$

Exponentional order for dependence on $\left(\mathrm{H}^{+}\right) \quad 0.5$

Gibbsite dissolution $k\left(\mathrm{~d}^{-1}\right) \quad 0.05$

Nitrification rate $k(d-1) \quad 0.30$

Gibbsite solubility $k\left(1^{2} \mathrm{~mol}-2\right) \quad 108.1$

Organic matter decay

Litter Fine litter Humus Organic acids

Mass (t ha- $\left.{ }^{-1}\right)$

First-order $k\left(\mathrm{yr}^{-1}\right)$

$\mathrm{N}$-loss fraction

Cation leaching fraction

$\begin{array}{lrcc}6.1 & 24.8 & 193 & \\ 1 & 0.2 & 0.015 & 0.10 \\ & 0.5 & 0.5 & \end{array}$

0.2

Monthly distribution

Litterfall (t ha- 1)

Nutrient uptake (\%)

Standing biomass ( $\mathrm{t} \mathrm{ha-1)}$

Productivity $(\mathrm{t} \cdot \mathrm{ha}-\mathrm{l} \cdot \mathrm{yr}-\mathrm{l})$

$\begin{array}{llllllllllll}\mathrm{J} & \mathrm{F} & \mathrm{M} & \mathrm{A} & \mathrm{M} & \mathrm{J} & \mathrm{J} & \mathrm{A} & \mathrm{S} & \mathrm{O} & \mathrm{N} & \mathrm{D} \\ & & & & & & & & & & & \\ 0 & 0 & 0 & 0.1 & 0.1 & 0.3 & 0.5 & 0.5 & 1 & 2 & 1.5 & 0.5 \\ 0 & 0 & 5 & 15 & 20 & 17 & 17 & 16 & 10 & 0 & 0 & 0\end{array}$

\section{Nutrient composition}

Leaves ( $\mathrm{mg} \mathrm{g}^{-1}$ )

Trunk (mg g-1)
K

10.7

1.5
$\mathrm{Ca}$

7.7

0.4
$\mathrm{Mg}$

1.9

0.2

20.5

1.9

0.3 


\section{J. J. M. VAN GRINSVEN ET AL.}

Table 2. Throughfall fluxes, and soil fluxes of water and solutes calculated by multiplying observed concentrations and observed (throughfall) or simulated (soil) water fluxes. All results are based on monthly values of fluxes and concentrations.

\begin{tabular}{|c|c|c|c|c|c|c|c|c|c|c|c|c|}
\hline & $\mathrm{H}_{2} \mathrm{O}$ & $\mathrm{H}$ & $\mathrm{K}$ & $\mathrm{Na}$ & $\mathrm{Ca}$ & $\mathrm{Mg}$ & $\mathrm{Al}$ & $\mathrm{NH}_{4}$ & $\mathrm{NO}_{3}$ & $\mathrm{SO}_{4}$ & $\mathrm{Cl}$ & $\mathrm{Si}$ \\
\hline \multirow[t]{2}{*}{ Year } & \multicolumn{12}{|c|}{ Throughfall flux } \\
\hline & $(\mathrm{mm})$ & \multicolumn{11}{|c|}{$\left(\mathrm{kmol}_{\mathrm{c}} \cdot \mathrm{ha}^{-1} \cdot \mathrm{yr}^{-1}\right)$} \\
\hline 81 & 517 & 0.17 & 0.85 & 0.95 & 0.57 & 0.38 & 0.00 & 3.18 & 0.95 & 3.18 & 1.17 & 0.00 \\
\hline 82 & 513 & 0.14 & 1.03 & 1.07 & 0.62 & 0.39 & 0.00 & 2.73 & 0.87 & 2.60 & 1.55 & 0.00 \\
\hline 83 & 624 & 0.03 & 1.58 & 1.20 & 0.74 & 0.62 & 0.00 & 3.06 & 1.24 & 3.19 & 1.48 & 0.00 \\
\hline 84 & 516 & 0.05 & 1.31 & 0.74 & 0.53 & 0.40 & 0.00 & 2.87 & 1.24 & 2.66 & 1.00 & 0.00 \\
\hline 85 & 536 & 0.08 & 1.08 & 0.99 & 0.61 & 0.38 & 0.00 & 2.45 & 0.95 & 2.12 & 1.11 & 0.00 \\
\hline 86 & 505 & 0.05 & 1.31 & 1.48 & 0.57 & 0.46 & 0.00 & 2.94 & 1.94 & 2.35 & 1.75 & 0.00 \\
\hline Sum & 3211 & 0.52 & 7.16 & 6.43 & 3.64 & 2.63 & 0.00 & 17.23 & 7.19 & 16.10 & 8.06 & 0.00 \\
\hline \multirow[t]{2}{*}{ Year } & \multicolumn{12}{|c|}{ Soil flux at $90 \mathrm{~cm}$ depth } \\
\hline & $\mathrm{mm}$ & \multicolumn{11}{|c|}{$\left(\mathrm{kmol}_{\mathrm{c}} \cdot \mathrm{ha}^{-1} \cdot \mathrm{yr}^{-1}\right)$} \\
\hline 81 & 188 & 0.05 & 0.31 & 0.45 & 0.73 & 0.52 & 2.85 & 0.09 & 1.00 & 3.00 & 0.42 & 0.72 \\
\hline 82 & 166 & 0.18 & 0.12 & 0.53 & 0.55 & 0.38 & 3.63 & 0.01 & 1.87 & 2.35 & 0.83 & 0.46 \\
\hline 83 & 264 & 0.30 & 0.21 & 0.71 & 0.96 & 0.48 & 4.98 & 0.02 & 2.92 & 3.53 & 1.23 & 0.75 \\
\hline 84 & 206 & 0.19 & 0.16 & 0.65 & 0.70 & 0.39 & 4.54 & 0.05 & 3.51 & 2.32 & 0.72 & 0.67 \\
\hline 85 & 112 & 0.12 & 0.14 & 0.32 & 0.56 & 0.32 & 3.28 & 0.00 & 3.24 & 1.04 & 0.32 & 0.33 \\
\hline 86 & 214 & 0.22 & 0.21 & 0.58 & 0.89 & 0.45 & 4.84 & 0.00 & 3.62 & 2.35 & 1.08 & 0.93 \\
\hline Sum & 1150 & 1.06 & 1.15 & 3.24 & 4.39 & 2.54 & 24.17 & 0.17 & 16.16 & 14.59 & 4.60 & 3.86 \\
\hline \multirow{2}{*}{$\begin{array}{l}\text { Depth } \\
\text { (cm) }\end{array}$} & \multicolumn{12}{|c|}{ Mean annual (1981-1987) solute flux } \\
\hline & $\mathrm{mm}$ & \multicolumn{11}{|c|}{$\left(\mathrm{kmol}_{\mathrm{c}} \cdot \mathrm{ha}^{-1} \cdot \mathrm{yr}^{-1}\right)$} \\
\hline $\mathrm{T}^{1}$ & 535 & 0.09 & 1.19 & 1.07 & 0.61 & 0.44 & 0.00 & 2.87 & 1.20 & 2.68 & 1.34 & 0.00 \\
\hline 10 & 472 & 3.23 & 1.45 & 0.91 & 1.77 & 0.97 & 2.03 & 0.65 & 5.72 & 2.97 & 1.11 & 1.46 \\
\hline 40 & 298 & 0.44 & 0.58 & 0.64 & 1.28 & 0.68 & 5.25 & 0.18 & 4.83 & 2.56 & 0.99 & 1.11 \\
\hline 90 & 192 & 0.18 & 0.19 & 0.54 & 0.73 & 0.42 & 4.02 & 0.03 & 2.69 & 2.43 & 0.77 & 0.64 \\
\hline $\begin{array}{l}\text { Depth } \\
\text { (cm) }\end{array}$ & & \multicolumn{11}{|c|}{$\begin{array}{l}\text { Mean annual (1981-1987) flux-weighted concentration } \\
\left(\mathrm{mol}_{\mathrm{c}} \mathrm{m}^{-3}\right)\end{array}$} \\
\hline $\mathrm{T}$ & & 0.02 & 0.22 & 0.20 & 0.11 & 0.08 & 0.00 & 0.54 & 0.23 & 0.50 & 0.25 & 0.00 \\
\hline 10 & & 0.70 & 0.31 & 0.20 & 0.38 & 0.21 & 0.44 & 0.14 & 1.22 & 0.63 & 0.24 & 0.32 \\
\hline 40 & & 0.15 & 0.19 & 0.22 & 0.43 & 0.23 & 1.79 & 0.06 & 1.65 & 0.88 & 0.34 & 0.38 \\
\hline 90 & & 0.09 & 0.10 & 0.28 & 0.39 & 0.23 & 2.16 & 0.01 & 1.51 & 1.25 & 0.39 & 0.33 \\
\hline
\end{tabular}

1 T stands for values in throughfall. 
The soil profile was divided into 5 soil compartments (Table 1), representing the litter layer, the A-, $\mathrm{B}_{1}-, \mathrm{B}_{2}$ - and C-horizon, respectively. Field capacity is the volumetric water content at $10 \mathrm{kPa}$ suction. Water uptake fractions are proportional to the compartment thicknesses, which was concluded from calibration of the SWATRE model (van Grinsven et al., 1987b). Nutrient uptake fractions were calibrated.

Selectivity coefficients for the Gaines-Thomas exchange equation (Eq. 1) were derived from mean annual flux-weighted concentrations in soil solution, and one analysis of exchangeable cations (Bascomb, 1964). Flux-weighted concentrations are the ratios of solute fluxes and water fluxes.

Anion adsorption was only considered for $\mathrm{PO}_{4}$ in order to prevent growth reduction as a result of $\mathrm{P}$-shortage. $\mathrm{SO}_{4}$ was considered to be a conservative ion, except for the complexation reaction with Al. Pools of silicate minerals were based on total elemental analyses, assuming that all $\mathrm{Na}$ was released from $\mathrm{Na}$-feldspar, all $\mathrm{K}$ from K-feldspar (van Grinsven, 1988). A fictive mineral of similar composition as anorthite was used as a pool for $\mathrm{Ca}$ and $\mathrm{Mg}$. All silicate minerals were assumed to dissolve incongruently to kaolinite (van Grinsven, 1988). Pseudo-first-order rate constants were set equal to $0.011^{0.5} \cdot \mathrm{mol}^{-0.5} \cdot \mathrm{yr}^{-1}$ for $\mathrm{K}$ and $\mathrm{Na}$ and 0.04 for $\mathrm{Ca}$ and $\mathrm{Mg}$, and the fractional exponent to 0.5 . Actual silicate weathering rates are calculated according to:

$$
\mathrm{d} M / \mathrm{d} t=k M\left(\mathrm{H}^{+}\right)^{0.5}
$$

where $M$ is actual mineral mass (mol ha-1), $t$ is time, and $k$ is the pseudo-firstorder rate constant. Resulting weathering fluxes for the individual base cations range from 0.25 to $0.4 \mathrm{kmol}_{\mathrm{c}} \cdot \mathrm{ha}^{-1} \cdot \mathrm{yr}^{-1}$, which is in accordance with weathering rates implied from field mass balance studies (van Breemen, 1986; Bloom \& Grigal, 1985; Velbel, 1985). Dissolution of $\mathrm{Al}(\mathrm{OH})_{3}$ was assumed to be the only mineral source of Al (van Grinsven, 1988). Rate constants for nitrification and gibbsite dissolution were calibrated.

Data for the chemical composition of tree leaves and trunk, as well as net forest growth, were determined in situ. Leaf exudation of particularly $\mathrm{K}, \mathrm{Ca}$ and $\mathrm{Mg}$ were not added to the throughfall input but to litterfall, as part of the cycling of elements through the vegetation. The $\mathrm{C}$ and $\mathrm{N}$-contents of the various organic matter fractions were calculated from elemental analyses of litter and soil samples. First-order decay constants were calculated assuming that present pools represent steady-state values. Litterfall data were obtained from van Breemen et al. (1988).

Hydrologic input consisted of daily throughfall and the evaporative demand for the soil surface and the vegetation. Daily throughfall was derived from daily rainfall and bi-weekly throughfall according to the procedure given in van Grinsven et al. (1987b). Evaporative demand was obtained from Penman data provided by the Royal Dutch Meteorological Institute.

Chemical input consisted of monthly concentrations in rainfall for all ions except $\mathrm{NH}_{4}, \mathrm{SO}_{4}$ and $\mathrm{H}$. Concentrations were multiplied by the monthly ratio of rainfall over throughfall to account for the concentration increase due to interception 
evaporation. Monthly concentration data for $\mathrm{NH}_{4}, \mathrm{SO}_{4}$ and $\mathrm{H}$ were equal to those observed in throughfall.

\section{Model calibration}

For calibration and validation of the model the period from April 1981 to April 1987 was considered. Hydrologic years were considered instead of calendar years to avoid large storage changes of water and solutes. The model was not calibrated with respect to soil hydrology. Approximate chemical calibration was accomplished by comparing simulated annual chemical soil fluxes from ILWAS with fluxes obtained by multiplying measured soil solution concentrations and soil water fluxes simulated by the SWATRE model (Feddes et al., 1978; van Grinsven et al., 1987b). Solute fluxes are summarized in Table 2. Specific calibration of the model was obtained by superimposing simulated time series of soil solution concentrations on field observations. Model parameters which were adjusted for calibration were (1) the decay rate constant and decay stoichiometry for litter and fine litter, (2) the soil nitrification rate constant, and (3) uptake distribution of nitrogen with depth, and (4) the gibbsite dissolution rate constant (Eq. 4). The period from April 1981 to April 1983 was used for calibration. It was difficult to calibrate the rate constants without causing major changes of the composition of the cation exchange complex, which is the most reactive source and sink of cations in the soil system. Although supporting data are scarce, we imposed the condition that during the simulation period changes of exchangeable concentrations should be small.

Plots of simulated time series of soil solution concentrations are based on mean values per $10 \mathrm{~d}$.

\section{Scenarios}

After calibration of the model, three scenarios with adjusted boundary conditions were evaluated:

(1) A $50 \%$ reduction of atmospheric deposition of $\left(\mathrm{NH}_{4}\right)_{2} \mathrm{SO}_{4}$

(2) Fertilization with $2.6 \mathrm{kmol}_{\mathrm{c}}$ ha-1 $\mathrm{K}_{2} \mathrm{SO}_{4}$ and $8.4 \mathrm{kmol}_{\mathrm{c}} \mathrm{ha}^{-1} \mathrm{MgSO}_{4}$

(3) Removal of the forest.

Reduction of deposition in Scenario 1 was started in April 1982. Scenario 2 is based on a fertilizer experiment in Harderwijk (the Netherlands) in a stand of Pinus sylvestris. The object of this experiment was to show that atmospheric deposition of $\mathrm{N}$ would be consumed by the vegetation provided that adequate amounts of $\mathrm{K}, \mathrm{Na}$, $\mathrm{Ca}$ and $\mathrm{P}$ were added. Ca was added as lime $\left(93 \mathrm{kmol}_{\mathrm{c}} \mathrm{ha}^{-1 \mathrm{CaO}}\right)$ to increase $\mathrm{pH}$ and to neutralize the acid effects of the sulphate fertilizers. The lime addition was not simulated. Therefore, the simulation by no means evaluates the integral fertilizer experiment. In Scenario 2 the fertilizers were added in December 1982. The addition of $\mathrm{K}_{2} \mathrm{SO}_{4}$ was mimicked as an increase in wet deposition for $\mathrm{K}$ and $\mathrm{SO}_{4}$, equally distributed over a period of three months. The $\mathrm{MgSO}_{4}$ was added as a new mineral to the forest floor dissolving with a first-order constant of $2 \mathrm{yr}^{-1}$.

For Scenario 3 we assumed that the forest was felled in March 1981 and that all 
woody parts were removed from the site. In view of the poor vitality of many coniferous forest stands in the Netherlands, clearfelling of forest stands followed by replantation may be considered. We assumed that in the following growing season the site was recovered by a ground vegetation. The assumed effects of this change of vegetation were a reduction by $50 \%$ of (1) water uptake, to account for reduced transpiration and interception, (2) nutrient demand, (3) litterfall, and (4) atmospheric deposition of $\left(\mathrm{NH}_{4}\right)_{2} \mathrm{SO}_{4}$. All reductions were started in April 1981 . Uptake of water and nutrients was confined to the upper 4 soil compartments (40 $\mathrm{cm}$ depth). The uptake distribution for water was changed to 30 \%-30 \%-20 \%$20 \%$ and for nutrients to $60 \%-20 \%-10 \%-10 \%$ in the upper four soil compartments (Table 1).

\section{Results and discussion}

\section{Simulation of water fluxes and $[\mathrm{Cl}]$}

The precipitation surplus simulated by ILWAS is about $20 \%$ higher than that simulated by SWATRE (Tables 2 and 3). For the SWATRE simulations, water uptake by roots was reduced below a water potential of $-50 \mathrm{kPa}$, according to a hyperbolic relationship with the water potential, as an alternative for the original linear relationship. In ILWAS, water uptake by roots is reduced proportional to $\theta$ below field capacity at $-10 \mathrm{kPa}$ (Table 1). Differences between soil water fluxes simulated by ILWAS and SWATRE at 10 and $40 \mathrm{~cm}$ depth are +12 and $-5 \%$, respectively, in-

Table 3. Mean annual ratios of observed over simulated values of water and solute fluxes, and fluxweighted concentrations, for the period from April 1981 to April 1987. Field values are based on observed concentrations and throughfall quantities and simulated unsaturated soil water fluxes.

\begin{tabular}{lllllllllllll}
\hline $\begin{array}{l}\text { Depth } \\
(\mathrm{cm})\end{array}$ & $\mathrm{H}_{2} \mathrm{O}$ & $\mathrm{H}$ & $\mathrm{K}$ & $\mathrm{Na}$ & $\mathrm{Ca}$ & $\mathrm{Mg}$ & $\mathrm{Al}$ & $\mathrm{NH}_{4}$ & $\mathrm{NO}_{3}$ & $\mathrm{SO}_{4}$ & $\mathrm{Cl}$ & $\mathrm{Si}$ \\
\cline { 2 - 11 } & \multicolumn{1}{l}{ Ratio of ion-equivalent fluxes } \\
\cline { 2 - 11 } $\mathrm{T}^{1}$ & 1.02 & ERR & 20.88 & 1.21 & 1.37 & 2.00 & $\mathrm{ERR}^{2}$ & 0.85 & 1.93 & 0.75 & 1.46 & $\mathrm{ERR}$ \\
10 & 1.12 & 0.97 & 1.58 & 1.31 & 0.81 & 1.02 & 3.02 & 3.88 & 0.96 & 0.81 & 1.15 & 7.68 \\
40 & 0.95 & 0.70 & 0.74 & 0.78 & 0.86 & 0.95 & 1.11 & $\mathrm{ERR}$ & 1.04 & 0.74 & 1.05 & 1.80 \\
100 & 0.79 & 0.70 & 0.31 & 0.57 & 0.55 & 0.64 & 0.93 & ERR & 0.75 & 0.72 & 0.83 & 0.44 \\
\hline
\end{tabular}

Ratio of flux-weighted ion-equivalent concentrations

\begin{tabular}{llrlllllllll}
\hline T & ERR & 17.84 & 1.14 & 1.29 & 1.89 & ERR & 0.78 & 1.58 & 0.72 & 1.35 & ERR \\
10 & 0.78 & 1.45 & 1.25 & 0.65 & 0.86 & 2.74 & 5.56 & 0.81 & 0.73 & 1.08 & 6.01 \\
40 & 1.09 & 0.93 & 0.85 & 0.97 & 1.02 & 1.10 & ERR & 1.10 & 0.78 & 1.10 & 1.76 \\
100 & 0.97 & 0.43 & 0.74 & 0.69 & 0.83 & 1.21 & ERR & 0.96 & 0.94 & 1.04 & 0.62 \\
\hline
\end{tabular}

$1 \mathrm{~T}$ stands for values in throughfall.

2 ERR indicates denominator zero. 


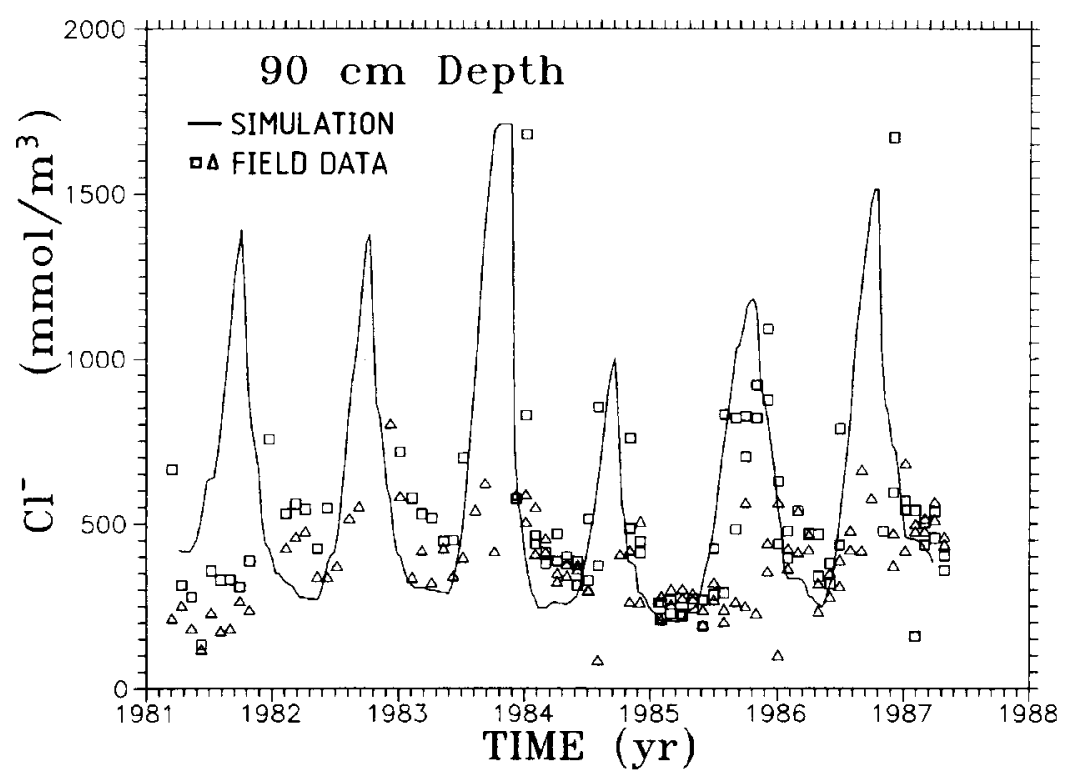

Fig. 1. Concentrations of $\mathrm{Cl}^{-}$at $90 \mathrm{~cm}$ depth from April 1981 to April 1987 simulated by the ILWAS model and observed in two field profiles.

dicating that differences in water uptake are largest in the fourth and fifth soil compartment. Reduction of water uptake by ILWAS will be most extreme when field capacity is low, as is the case for compartment 5.

Simulated and measured concentrations of $\mathrm{Cl}$ at $90 \mathrm{~cm}$ depth are shown in Fig. 1. $\mathrm{Cl}$ is a conservative ion in ILWAS, except for negligible mineralization and uptake. ILWAS predicts extreme concentration peaks near the end of summer and in autumn. Such concentration peaks are not generally observed in the field, except in 1985. Isolated peak concentrations of $\mathrm{Cl}$ were observed in 1983, 1984 and 1986. In general, ILWAS simulates no net flow of water below a depth of $40 \mathrm{~cm}$ between July and November, which causes a continuous gradual decrease of the water content and increase of $[\mathrm{Cl}]$. The SWATRE model generally simulated small upward capillary fluxes, in the order of $5 \mathrm{~mm}$ per month (van Grinsven et al., 1987b), from the groundwater near the end of summer and in autumn. Capillary rise of relatively dilute groundwater may explain why extremely high concentrations are not observed. In addition, lysimeter cups do not always yield soil solution samples in dry periods, as indicated by fewer field data during occurrence of peak concentrations. This problem is smallest at $90 \mathrm{~cm}$ depth, due to the proximity of groundwater (about $1.5 \mathrm{~m}$ depth). However, one may doubt the representativeness of water samples in dry periods, because of the possibility of water transport from wetter dilute soil domains to the lysimeter cups. The occurrence of extremely high solute concentrations in sandy subsoils near the end of the growing season was confirmed by soil solution samples obtained by the centrifuge method. As high $[\mathrm{Cl}]$ coincide with low or zero 
water fluxes, the possibly inaccurate prediction of [Cl] by ILWAS in the dry season has no great effect on fluxes of $\mathrm{Cl}$. Differences between observed and simulated annual fluxes of $\mathrm{Cl}$ are similar to those of the water fluxes, and differences of flux weighted concentrations are even smaller (Table 3).

\section{Annual solute fluxes and flux weighted concentrations (FWC)}

On average, predicted solute fluxes from the soil profile are $30 \%$ higher than those implied from field mass balances (Table 3), of which $15 \%$ is caused by overestimation of water fluxes. Differences between solute fluxes in field throughfall and throughfall used for ILWAS input represent the annual leaf leachate fluxes. Disagreement between predictions and field estimates of FWC are apparent for $\mathrm{K}, \mathrm{Si}$ at all depths, and for $\mathrm{NH}_{4}$ and $\mathrm{Al}$ (total aqueous $\mathrm{Al}$ assuming a charge of $3+$ ) at $10 \mathrm{~cm}$ depth. Differences for $\mathrm{Si}$ are caused by not considering reprecipitation of $\mathrm{Si}$ in the ILWAS model. After its release from silicate minerals, $\mathrm{Si}$ is regarded as an inert component in ILWAS, resulting in a steady increase of the Si flux with depth. However, in the field the highest fluxes of $\mathrm{Si}$ are observed in the surface horizon, indicating the formation of secondary silicate minerals at greater depths. Larger fluxes of $\mathrm{Si}$ in the field may imply mobilization of $\mathrm{Al}$ from silicate minerals in the surface horizons, which was not considered in the present ILWAS runs, and which may explain part of the underestimation of the Al-flux at $10 \mathrm{~cm}$ depth.

Rate constants for dissolution of gibbsite were the same for all soil compartments. Further increase of the gibbsite rate constant to simulate higher fluxes of $\mathrm{Al}$ at 10 $\mathrm{cm}$ depth caused no increase of the convective Al-flux, but instead caused excessive exchange of $\mathrm{Al}$ against $\mathrm{H}$. The consideration of both $\mathrm{Al}$-exchange and fast dissolution of $\mathrm{Al}$ from gibbsite may lead to in situ transfer of $\mathrm{Al}$ from oxides to the exchange complex, where either precipitation of gibbsite or the exchange complex may act as proton donor. This feature was actually simulated in the hydrologic year 1984-1985 where gibbsite dissolution was $10.5 \mathrm{kmol}_{\mathrm{c}}$ ha-1, which is about twice as high as in the other five years, and could not be explained by higher proton production from nitrification. The additional $\mathrm{Al}$ from gibbsite weathering was exchanged against $\mathrm{H}$ and $\mathrm{Ca}$.

The underestimation of the $\mathrm{NH}_{4}$-flux at $10 \mathrm{~cm}$ could not be solved by decreasing the nitrification rate, because this caused an underestimation of the $\mathrm{NO}_{3}$-flux from the soil profile. The throughfall fluxes of $\mathrm{NH}_{4}$ and $\mathrm{NO}_{3}$ for model input were 3.5 $\mathrm{kmol}^{\mathrm{ha}} \mathrm{-}^{-1}$ higher and lower, respectively, than the observed fluxes, because significant dry deposition of $\mathrm{NH}_{4} \mathrm{NO}_{3}$ from 1984 to 1986 was not considered.

The overestimation of the $\mathrm{K}$ flux at $100 \mathrm{~cm}$ may indicate overestimation of the weathering rate of $\mathrm{K}$. Also simulated fluxes of $\mathrm{Ca}, \mathrm{Mg}$ and $\mathrm{NO}_{3}$ from the soil profiles are 25 to $35 \%$ (Table 3 ) higher than implied from the field budgets. The main causes for these discrepancies are cation exchange and net mineralization (Table 4). Net mineralization of base cations was an unintentional effect of our assumption that only $90 \%$ of the $\mathrm{N}$ load in litterfall is taken up, to account for direct luxury uptake of $\mathrm{N}$ by the tree canopy. Internally, ILWAS translates reduction of uptake of $\mathrm{N}$ to uptake reduction of all nutrients. Net exchange of base cations is very 
Table 4. Chemical balances for calibrated ILWAS simulation, over the period from April 1981 to April 1987.

\begin{tabular}{|c|c|c|c|c|c|c|c|c|c|c|c|}
\hline & $\mathrm{H}$ & K & $\mathrm{Na}$ & $\mathrm{Ca}$ & $\mathrm{Mg}$ & $\mathrm{Al}$ & $\mathrm{NH}_{4}$ & $\mathrm{NO}_{3}$ & $\mathrm{SO}_{4}$ & $\mathrm{Cl}$ & $\mathrm{Si}$ \\
\hline & \multicolumn{11}{|c|}{$\left(\mathrm{kmol}_{\mathrm{c}} \mathrm{ha}^{-1}\right)$} \\
\hline Deposition & 0.0 & 0.3 & 5.3 & 2.7 & 1.3 & 0.0 & 20.7 & 3.8 & 21.9 & 5.5 & 0.0 \\
\hline Leaching & -1.5 & -3.8 & -5.8 & -8.1 & -4.0 & -27.1 & 0.0 & -22.5 & -21.1 & -5.6 & -9.0 \\
\hline Exchange & 1.3 & 0.6 & -1.6 & 1.4 & 0.2 & -9.7 & 1.1 & 0.0 & 0.0 & 0.0 & 0.0 \\
\hline Weathering & -45.2 & 2.4 & 2.2 & 2.0 & 1.8 & 36.7 & 0.0 & 0.0 & 0.0 & 0.0 & 8.7 \\
\hline Net-mineralization & -80.7 & 0.5 & 0.0 & 1.9 & 0.6 & 0.0 & 36.5 & -40.3 & -1.1 & 0.0 & 0.0 \\
\hline Nitrification & 118.8 & 0.0 & 0.0 & 0.0 & 0.0 & 0.0 & -59.4 & 59.4 & 0.0 & 0.0 & 0.0 \\
\hline Storage & -0.2 & -0.1 & -0.1 & 0.2 & 0.2 & -0.0 & 0.4 & -0.4 & 0.0 & 0.1 & 0.3 \\
\hline Balance & -7.6 & -0.1 & 0.0 & 0.0 & 0.0 & -0.1 & -0.7 & -0.0 & -0.3 & -0.0 & 0.0 \\
\hline
\end{tabular}

difficult to control in the model, because yearly variation of soil solution concentrations unavoidably leads to instantaneous variation of adsorbed concentrations. In this respect, the use of annual FWC for 1981 as initial condition for ILWAS may have been unfortunate. Annual FWC are artificial concentration values and, moreover, concentrations in the first year of monitoring differed somewhat (Table 2) from observations in the following years.

Chemical balances of $\mathrm{H}, \mathrm{NH}_{4}$ and $\mathrm{NO}_{3}$ (Table 4) illustrate the importance of internal processes. The net flux of $\mathrm{H}^{+}$from the soil system is less than $1 \%$ of the total flux, which is mainly associated with nitrification of $\mathrm{NH}_{4}$ from mineralization. The balance of $\mathrm{H}^{+}$is not tight which is caused by a cumulative truncation error in the modified cation exchange module in ILWAS.

\section{Simulation of time series of concentration}

Simulated $\left[\mathrm{H}^{+}\right]$in compartments 2 through 4 were generally higher than observed concentrations, which is illustrated for $10 \mathrm{~cm}$ depth in Fig. 2. Observed and simulated FWC compare rather well (Table 3), which is mainly caused by underestimation of $\left[\mathrm{H}^{+}\right]$in the first hydrologic year. There is no distinct seasonal pattern for $\left[\mathrm{H}^{+}\right]$ at $10 \mathrm{~cm}$ depth. Simulated short-term variation of $\left[\mathrm{H}^{+}\right]$, which is mainly the result of variation of the nitrification of $\mathrm{NH}_{4}$ from atmospheric deposition and mineralization of organic matter, is more extreme than the observed variation. Field observations suggest a very gradual increase of $\left[\mathrm{H}^{+}\right]$over the six-year period, not considering the first hydrologic year.

Simulated $\left[\mathrm{Al}^{3+}\right]$ (Fig. 3) at $40 \mathrm{~cm}$ depth shows a distinct seasonal pattern which is associated with increasing concentration of the soil solution due to water uptake by roots, as was discussed for $\mathrm{Cl}$. However, the height of the peaks of $\left[\mathrm{Al}^{3+}\right]$ is not correlated with the height of the peaks for [Cl], but is modified by gibbsite precipitation due to supersaturation. Furthermore, the height of the Al-peaks is associated with the transport of $\mathrm{Al}$ from the upper soil compartments just before the start of 


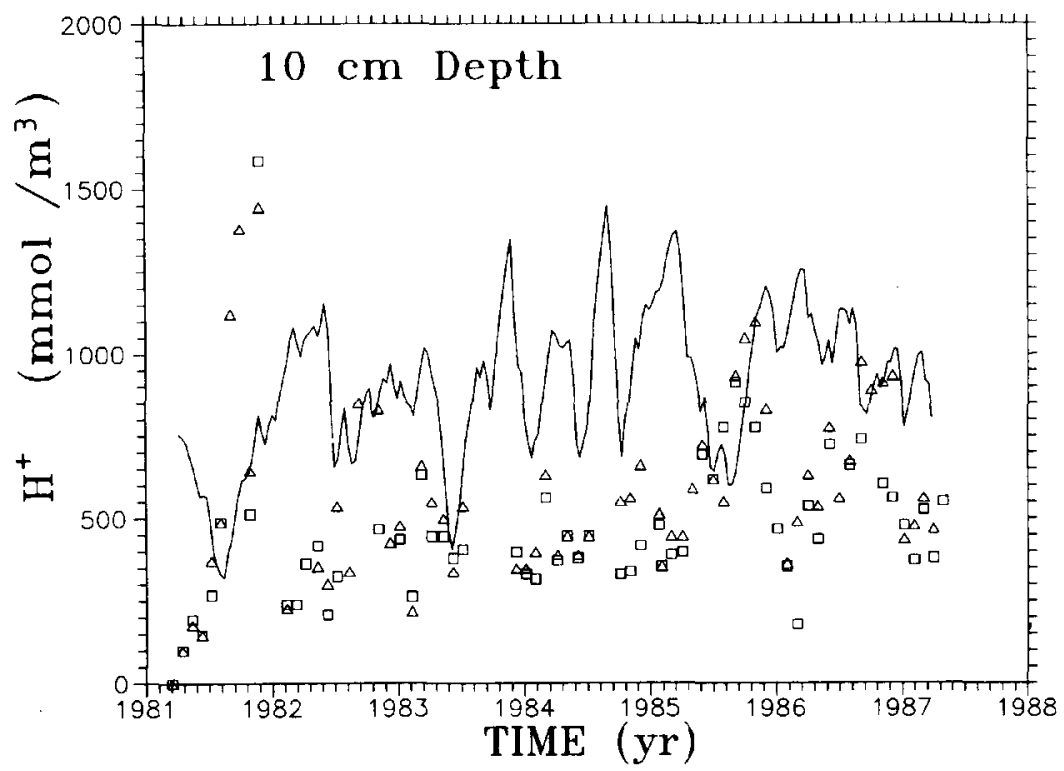

Fig. 2. Concentrations of $\mathrm{H}^{+}$at $10 \mathrm{~cm}$ depth from April 1981 to April 1987 simulated by the ILWAS model and observed in two field profiles.

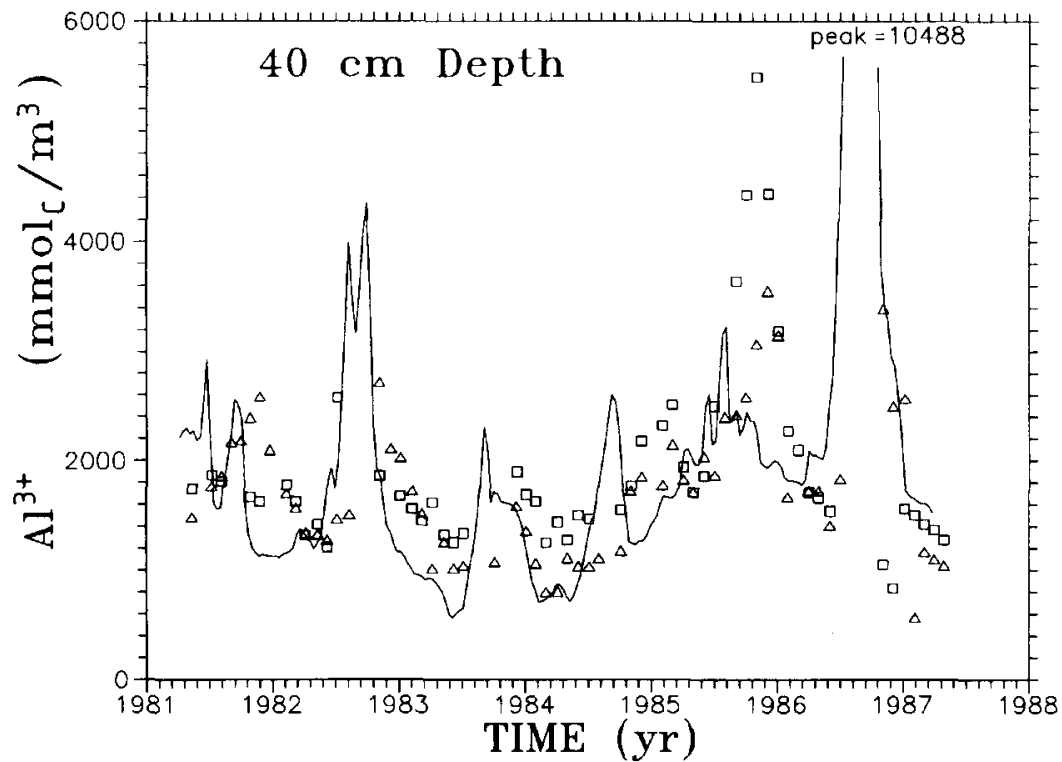

Fig. 3. Concentrations of $\mathrm{Al}^{3+}$ at $40 \mathrm{~cm}$ depth from April to April 1987 simulated by the ILWAS model and observed in two field sites. 


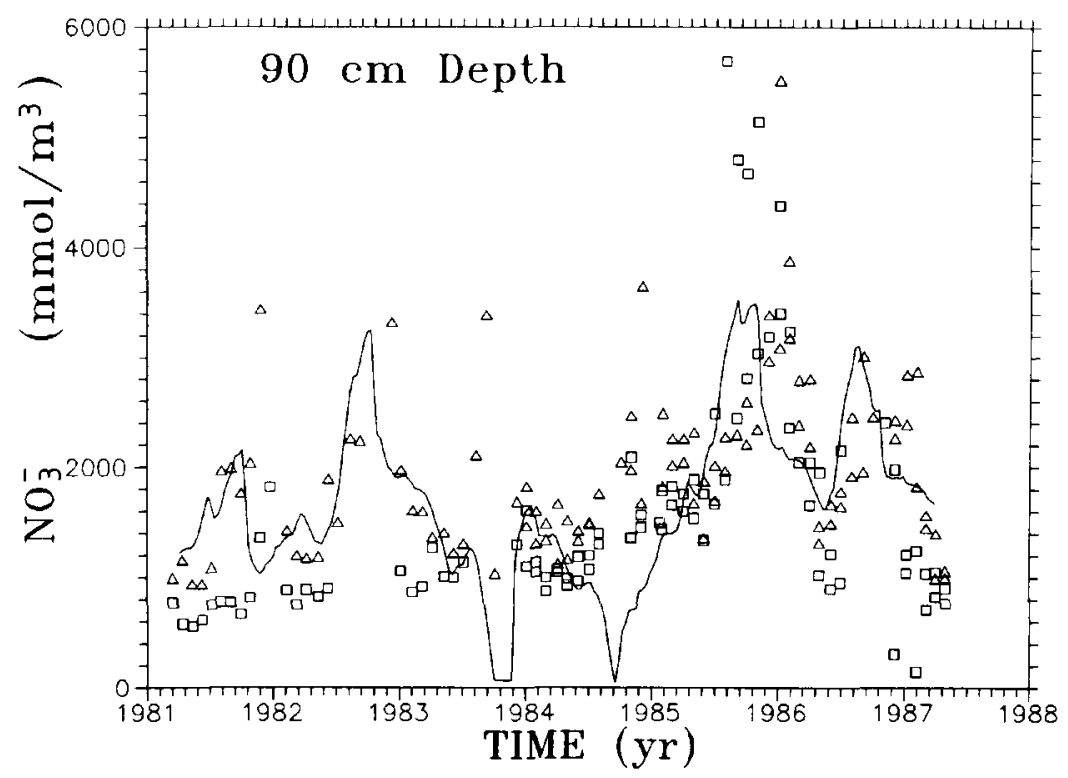

Fig. 4. Concentrations of $\mathrm{NO}_{3}$-at $90 \mathrm{~cm}$ depth from April 1981 to April 1987 simulated by the ILWAS model and observed in two field profiles.

the dry season. Al-transport is in part associated with transport of $\mathrm{NO}_{3}$, which was distinctly higher in the summer of 1985 (Fig. 4). The summer of 1985 was the only year where a peak of $\mathrm{Al}$ was observed, which was distinctly higher than the simulated peak. Simulated values of $\left[\mathrm{Al}^{3+}\right]$ compare well with field observations except for the peak values in summer. The possible causes for not observing peak concentrations were discussed for $\mathrm{Cl}$. Although peak concentrations of $\mathrm{Al}$ are irrelevant for Al-transport, they may be relevant with respect to the biological functioning of roots and soil micro-flora and -fauna.

Concentrations of $\mathrm{NO}_{3}$ throughout the soil profile were simulated well, as illustrated for $90 \mathrm{~cm}$ depth (Fig. 4) and earlier by the agreement between simulated and observed FWC (Table 3). Higher $\left[\mathrm{NO}_{3}\right]$ in the summers of 1985 and 1986, relative to the other years, are both simulated and observed. The $\left[\mathrm{NO}_{3}\right]$ in the subsoil towards the end of the growing season, when there is no net water transport, can become both extremely low and extremely high because of the counteracting effects of uptake of $\mathrm{NO}_{3}$ and water. Peak values of $\left[\mathrm{NO}_{3}\right]$ are simulated in all summers, except in 1983 and 1984 , when $\left[\mathrm{NO}_{3}\right]$ becomes practically zero. The critical process determining the occurrence of either high or low concentration extremes is mineralization of organic $\mathrm{N}$ and subsequent downward transport of $\mathrm{NO}_{3}$ just before start of the dry season. Mineralization of organic $\mathrm{N}$ in ILWAS depends on temperature according to:

$$
\mathrm{d} X / \mathrm{d} t=k X 1.05^{(\mathrm{T}-12)}
$$




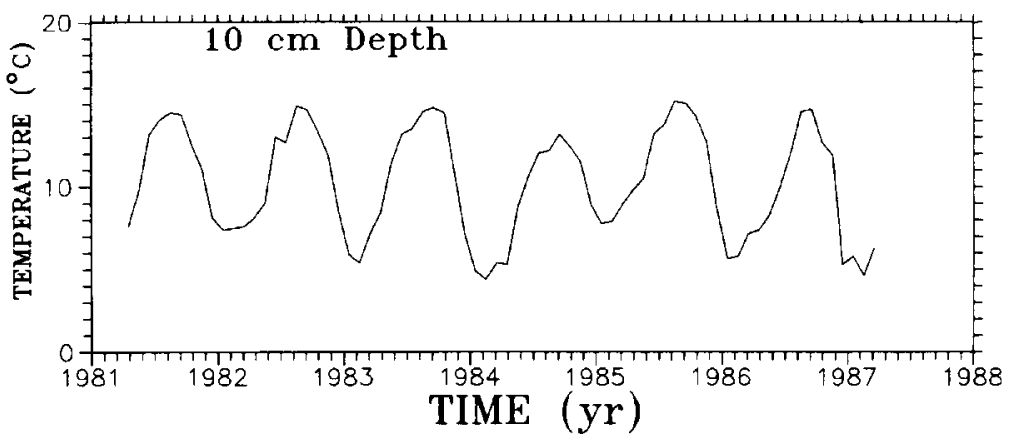

Fig. 5. Simulated soil temperature at $10 \mathrm{~cm}$ depth.

where $X$ is the amount of organic $\mathrm{N}(\mathrm{t} / \mathrm{ha}), k$ is the first-order rate constant $\left(\mathrm{yr}^{-1}\right)$, 1.05 is an empirical temperature factor, $T$ is the temperature $\left({ }^{\circ} \mathrm{C}\right)$ and $12{ }^{\circ} \mathrm{C}$ if the no-effect temperature. As simulated soil temperatures in the forest floor vary between 6 and $15{ }^{\circ} \mathrm{C}$ (Fig. 5), the simulated maximum difference between mineralization rates in winter and summer is only $50 \%$. In previous calibration runs this led to zero concentrations of $\mathrm{NO}_{3}$, and subsequent $\mathrm{N}$-shortage for forest growth, in every growing season. To increase this difference to $500 \%$, the temperature factor was increased to 1.2 and the no-effect temperature was decreased to $8^{\circ} \mathrm{C}$. Temperature correction of rate constants in ILWAS is a fixed procedure which may have been chosen for simulation of soil processes in alpine coniferous forest ecosystems. Simulated soil temperatures in the winter of 1984 and the spring of 1985 were distinctly higher than in the other years (Fig. 5), which caused a $10 \%$ increase of mineralization of organic N. The hydrologic year 1985-1986 was the only year where mineralization of $\mathbf{N}$ was higher than total uptake. Simulated $\left[\mathrm{NO}_{3}\right]$ in the subsoil is also extremely sensitive to the distribution of $\mathrm{N}$-uptake with depth, as changing the uptake fractions by just a few percent may turn a maximum of $\left[\mathrm{NO}_{3}\right]$ into a minimum. The model might be improved by relating the kinetics of organic matter decay to the simulation of the microbial population dynamics, instead to instantaneous temperature effects. Further improvement of the model may be obtained by considering flexible uptake distribution of $\mathrm{N}$ with depth, in relation to $\mathrm{N}$ availability and water content.

$50 \%$ reduction of atmospheric deposition of $\left(\mathrm{NH}_{4}\right)_{2} \mathrm{SO}_{4}$

A self-evident decrease of the $\left[\mathrm{H}^{+}\right]$after reduction of atmospheric deposition by $50 \%$ is not predicted. The average decrease of FWC of $\mathrm{H}^{+}$is about $10 \%$ in all soil compartments. The decrease of $\left[\mathrm{H}^{+}\right]$at $10 \mathrm{~cm}$ depth (Fig. 6) is not evenly distributed in time, but varies between 0 and $50 \%$, depending on whether net production of $\mathrm{H}^{+}$is associated with nitrification of atmospheric $\mathrm{N}$ or organic $\mathrm{N}$. The decrease of $\left[\mathrm{Al}^{3+}\right]$ is the most apparent effect of reduced deposition. Fluxes (and FWC's) decrease by $44 \%, 30 \%$ and $35 \%$ at 10,40 and $100 \mathrm{~cm}$ depth, respectively 


\section{J. J. M. VAN GRINSVEN ET AL.}

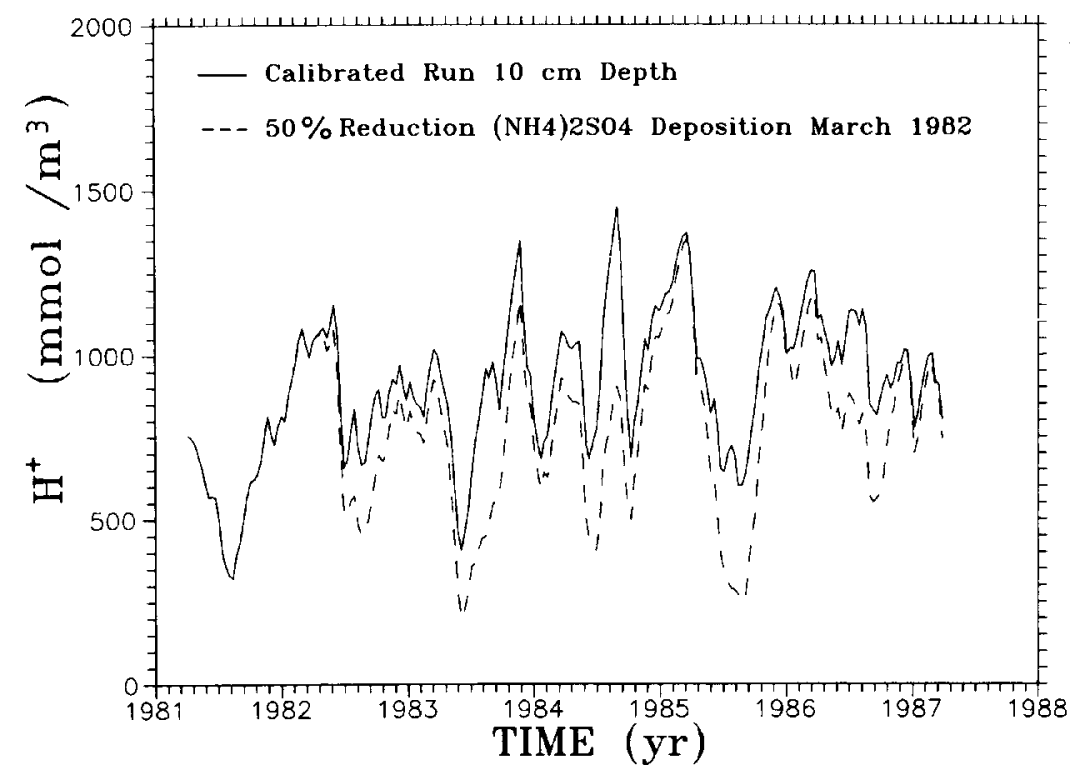

Fig. 6. Simulated concentrations of $\mathrm{H}^{+}$at $10 \mathrm{~cm}$ depth from April 1981 to April 1987 for present rates of atmospheric deposition of $\left(\mathrm{NH}_{4}\right)_{2} \mathrm{SO}_{4}$, and after reduction of deposition by $50 \%$ in April 1982.

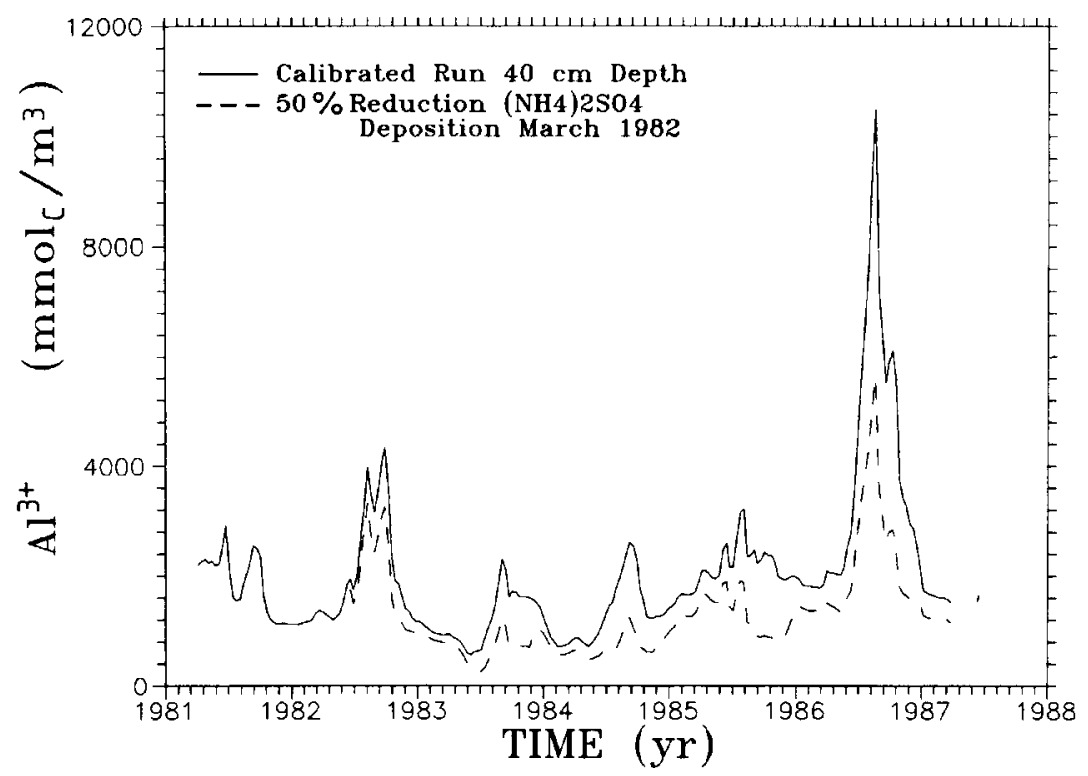

Fig. 7. Simulated concentrations of $\mathrm{Al}^{3+}$ at $40 \mathrm{~cm}$ depth from April 1981 to April 1987 for present rates of atmospheric deposition of $\left(\mathrm{NH}_{4}\right)_{2} \mathrm{SO}_{4}$, and after reduction of deposition by $50 \%$ in April 1982. 
Table 5. Simulated mean annual solute fluxes in throughfall $(\mathrm{T})$ and at 10,40 and $100 \mathrm{~cm}$ soil depth, for (1) the calibration run, (2) after $50 \%$ reduction of $\left(\mathrm{NH}_{4}\right)_{2} \mathrm{SO}_{4}$, (3) after adding $1.4 \mathrm{kmol} \mathrm{ha}{ }^{-1} \mathrm{~K}_{2} \mathrm{SO}_{4}$ and $4.7 \mathrm{kmol} \mathrm{ha}^{-1} \mathrm{Mg} \mathrm{SO}_{4}$, and (4) after clearcutting.

\begin{tabular}{llllllllllllll}
\hline $\begin{array}{l}\text { Depth } \\
\text { (cm) }\end{array}$ & $\mathrm{H}_{2} \mathrm{O}$ & $\mathrm{H}$ & $\mathrm{K}$ & $\mathrm{Na}$ & $\mathrm{Ca}$ & $\mathrm{Mg}$ & $\mathrm{Al}$ & $\mathrm{NH}_{4}$ & $\mathrm{NO}_{3}$ & $\mathrm{SO}_{4}$ & $\mathrm{CL}$ & $\mathrm{Si}$ \\
\hline
\end{tabular}

Calibration run

$\begin{array}{lllllllllllll}\mathrm{T} & 525 & 0.00 & 0.05 & 0.88 & 0.45 & 0.22 & 0.00 & 3.45 & 0.63 & 3.65 & 0.92 & 0.00 \\ 10 & 423 & 3.63 & 1.15 & 0.71 & 2.23 & 0.97 & 1.68 & 0.17 & 6.11 & 3.72 & 0.96 & 0.20 \\ 40 & 312 & 0.66 & 0.80 & 0.83 & 1.47 & 0.74 & 4.80 & 0.00 & 4.81 & 3.54 & 0.95 & 0.63 \\ 100 & 257 & 0.25 & 0.64 & 0.96 & 1.35 & 0.67 & 4.52 & 0.00 & 3.75 & 3.52 & 0.94 & 1.49\end{array}$

$50 \%$ reduction of deposition

$\begin{array}{llllllllllll}10 & 3.21 & 1.10 & 0.64 & 1.63 & 0.68 & 0.93 & 0.16 & 5.35 & 2.10 & 0.96 & 0.19 \\ 40 & 0.60 & 0.64 & 0.74 & 1.18 & 0.52 & 3.37 & 0.00 & 4.12 & 2.04 & 0.95 & 0.66 \\ 100 & 0.22 & 0.50 & 0.88 & 0.97 & 0.48 & 2.97 & 0.00 & 3.10 & 2.00 & 0.94 & 1.45\end{array}$

Fertilizer addition

$\begin{array}{llllllllllll}10 & 3.97 & 1.73 & 0.75 & 2.75 & 1.71 & 2.68 & 0.22 & 6.81 & 6.20 & 0.96 & 0.22 \\ 40 & 0.71 & 1.19 & 0.87 & 2.24 & 1.48 & 5.26 & 0.00 & 5.74 & 6.08 & 0.95 & 0.73 \\ 100 & 0.30 & 1.04 & 1.07 & 2.62 & 1.35 & 5.50 & 0.00 & 4.41 & 5.95 & 0.94 & 1.65\end{array}$

\begin{tabular}{lllllllllllll} 
Clearcutting & & & & & & & & & & & & \\
$\mathbf{T}$ & 525 & 0.00 & 0.06 & 0.88 & 0.45 & 0.22 & 0.00 & 1.45 & 0.63 & 1.63 & 0.92 & 0.00 \\
10 & 398 & 3.69 & 1.51 & 0.71 & 2.53 & 1.08 & 2.43 & 0.17 & 8.88 & 2.35 & 0.96 & 0.22 \\
40 & 340 & 0.70 & 1.53 & 0.85 & 2.61 & 1.21 & 5.30 & 0.00 & 8.72 & 2.40 & 0.94 & 0.69 \\
100 & 340 & 0.31 & 1.71 & 0.99 & 2.66 & 1.27 & 5.43 & 0.00 & 8.70 & 2.48 & 0.97 & 1.43 \\
\hline
\end{tabular}

(Table 5). The effect is almost immediate and reaches its maximum proportion in the second year after the reduction, in accordance with a time period of about one year to flush the soil profile. The reduction of the $\left[\mathrm{Al}^{3+}\right]$ at $40 \mathrm{~cm}$ depth is consistent throughout all seasons (Fig. 7). The reduction of the leaching of $\mathrm{NO}_{3}$ from the soil profile between 1982 and 1987 is only $15 \%$ (Table 5 ). The maximum reduction to be expected in the five-year period is $44 \%$ instead of $50 \%$, because simulated leaching in this period is partly caused by net mineralization and net exchange of $\mathrm{N}$ (Table 4). The relatively small reduction of $\mathrm{NO}_{3}$ leaching is caused by the strong delay of reduced leaching of atmospheric $\mathrm{N}$, due to an additional loss of $3.4 \mathrm{kmol}$ ha-1 $\mathrm{NH}_{4}$ from the exchangeable pool between 1982 and $1987(18 \%)$, and because part of the leaching of atmospheric $\mathrm{N}$ passes through the organic pools $(11 \%)$. The latter effect will continue to play a role over a long period of time. In fact, net leaching of $\mathrm{N}$ from organic pools is caused by net mineralization of $\mathrm{N}$ outside the growing season, which loss is compensated by net uptake of $\mathrm{N}$ from atmospheric deposition within the growing season. 


\section{J. J. M. VAN GRINSVEN ET AL.}

Table 6. The simulated fate of $1.4 \mathrm{kmol} \mathrm{ha}^{-1} \mathrm{~K}_{2} \mathrm{SO}_{4}$ and $4.7 \mathrm{kmol} \mathrm{ha}{ }^{-1} \mathrm{MgSO}_{4}$, added as fertilizer in December 1982, and effects on exchange and leaching of $\mathrm{Ca}$ and $\mathrm{Al}$, as compared to a simulation without fertilizer addition.

\begin{tabular}{|c|c|c|c|c|c|c|c|c|c|c|}
\hline \multirow[t]{2}{*}{ Year } & \multicolumn{2}{|c|}{$\begin{array}{l}\text { Fertilizer } \\
\text { addition } \\
\left(\mathrm{kmol}_{\mathrm{c}} \mathrm{ha}^{-1}\right)\end{array}$} & \multicolumn{4}{|c|}{$\begin{array}{l}\text { Exchangeable amount } \\
\left(\mathrm{kmol}_{\mathrm{c}} \mathrm{ha}^{-1}\right)\end{array}$} & \multicolumn{4}{|c|}{$\begin{array}{l}\text { Cumulative leaching } 1 \\
\left(\mathrm{kmol}_{\mathrm{c}} \mathrm{ha}^{-1)}\right.\end{array}$} \\
\hline & $\mathrm{K}$ & $\mathrm{Mg}$ & $\mathbf{K}$ & $\mathrm{Ca}$ & $\mathrm{Mg}$ & $\mathrm{Al}$ & $\mathrm{K}$ & $\mathrm{Ca}$ & $\mathrm{Mg}$ & $\mathrm{Al}$ \\
\hline 1983 & 2.80 & 4.26 & 2.33 & -1.89 & 2.97 & 1.16 & 0.07 & 0.32 & 0.18 & 1.06 \\
\hline 1984 & & 5.18 & 1.56 & -3.34 & 6.73 & -4.93 & 0.90 & 3.04 & 1.92 & 7.76 \\
\hline 1985 & & & 1.16 & -3.34 & 6.31 & -6.45 & 1.39 & 3.40 & 2.39 & 7.09 \\
\hline 1986 & & & 0.88 & -3.32 & 5.86 & -5.11 & 1.75 & 3.41 & 2.84 & 5.84 \\
\hline 1987 & & & 0.69 & -3.22 & 5.47 & -4.28 & 2.00 & 3.25 & 3.31 & 4.85 \\
\hline
\end{tabular}

1 Relative to case with no fertilizer addition.

\section{Addition of $\mathrm{K}_{2} \mathrm{SO}_{4}$ and $\mathrm{MgSO}_{4}$}

The added amounts of ionic $\mathrm{K}$ and $\mathrm{Mg}$ as fertilizer are initially stored on the exchange complex, while removing mainly exchangeable $\mathrm{Ca}$ and $\mathrm{Al}$. Four years after the fertilizer addition $29 \%$ of added $\mathrm{K}$ and $64 \%$ of added $\mathrm{Mg}$ are still retained on the exchange complex (Table 6). Fertilizer addition has caused an additional loss of $3.25 \mathrm{kmol}_{\mathrm{c}}$ ha $\mathrm{Ca}$ from the exchange complex. Mean annual fluxes and concentrations of $\mathrm{K}, \mathrm{Ca}$ and $\mathrm{Mg}$ are increased by $45 \%, 51 \%$ and $87 \%$ respectively (Table 5). In 1983, the year after the fertilizer is added, a salt shock is predicted, when the combined addition of $\mathrm{K}$ and $\mathrm{Mg}$ exchanges against almost $5 \mathrm{kmol}_{\mathrm{c}} \mathrm{ha}^{-1} \mathrm{Al}$. This high additional release of $\mathrm{Al}$ results in $\left[\mathrm{Al}^{3+}\right]$ as high as $18 \mathrm{mmol}_{\mathrm{c}} \mathrm{l}^{-1}$ in late summer at $40 \mathrm{~cm}$ depth (Fig. 8). A true evaluation by ILWAS of the benefit of the fertilizer operations is not possible without including soil liming. A major practical problem when liming full-grown forest stands is that the liming material can only be applied to the surface of the forest floor. Liming will increase $\mathrm{pH}$ in the forest floor and cause enhanced mineralization and nitrification of mineralized $\mathrm{NH}_{4}$. So after addition of $\mathrm{K}_{2} \mathrm{SO}_{4}$ and $\mathrm{MgSO}_{4}$, a concentrated solution of nitrates and sulfates of $\mathrm{K}, \mathrm{Ca}$ and $\mathrm{Mg}$ would infiltrate in the mineral soil and still cause a salt shock. It is not clear whether extremely high $\left[\mathrm{H}^{+}\right]$and $\left[\mathrm{Al}^{3+}\right]$ during one growing season would cause long-term damage to the forest. Salt shocks may be prevented by adding slow-release fertilizers, e.g. basalt powder, which do not produce anions of strong acids.

\section{Removal of forest vegetation}

The expression of removal of the forest vegetation into adjustments of model parameters is very approximate, but accounts for the major effects. The predominant simulated effect is a large increase of net mineralization, because element cycling for the former forest is assumed twice as high as for the succeeding 


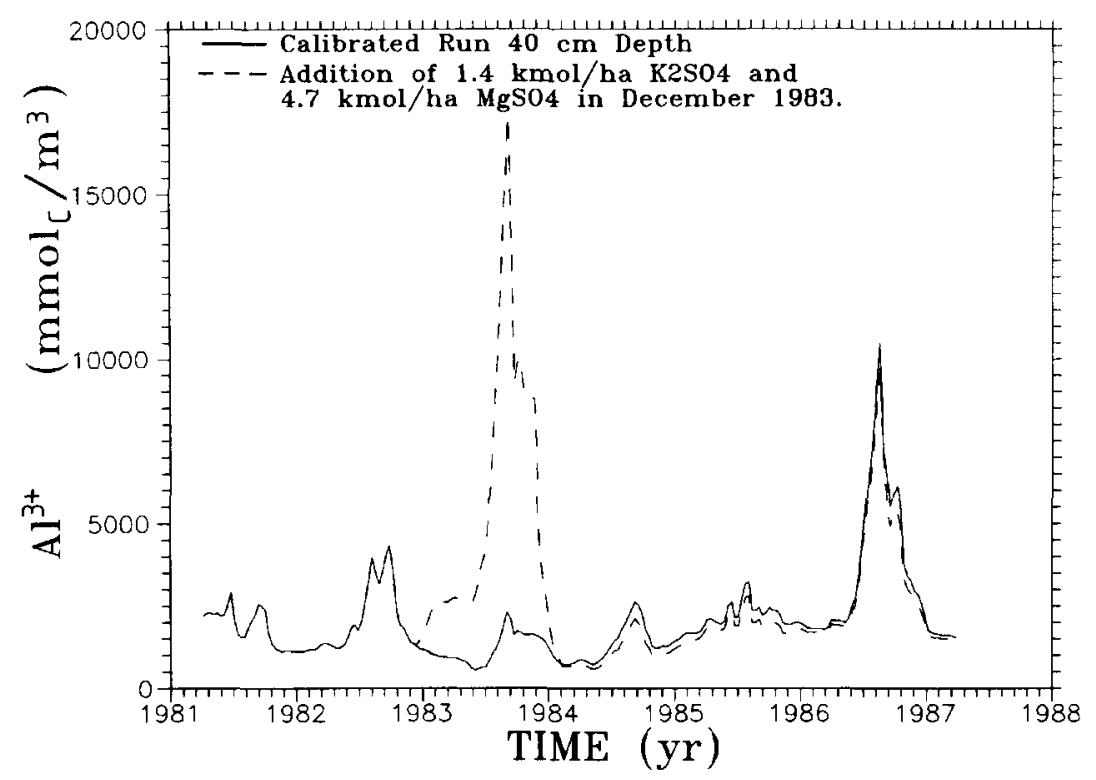

Fig. 8. Simulated concentrations of $\mathrm{Al}^{3}+$ at $40 \mathrm{~cm}$ depth from April 1981 to April 1987 for the calibrated model run and after addition of $1.4 \mathrm{kmol} \mathrm{ha}^{-1} \mathrm{~K}_{2} \mathrm{SO}_{4}$ and $4.7 \mathrm{kmol} \mathrm{ha}{ }^{-1} \mathrm{MgSO}_{4}$ in December 1982 .

ground vegetation. The average annual increase of the $\mathrm{NO}_{3}$-leaching from the soil profile is $4.94 \mathrm{kmol} \mathrm{ha}^{-1}$ (Table 5). The additional proton production due to net nitrification of mineralized $\mathrm{NH}_{4}$ is buffered mainly by net mineralization of base cations at an annual average rate of $2.5 \mathrm{kmol}_{\mathrm{c}} \mathrm{ha}^{-1}$. The total leaching of $\mathrm{Al}$ over the six year period increases by $20 \%$ in spite of the reduction of the atmospheric deposition of $\left(\mathrm{NH}_{4}\right)_{2} \mathrm{SO}_{4}$ by $50 \%$, due to production of $\mathrm{H}^{+}$from nitrification of mineralized $\mathrm{NH}_{4}$. Net mineralization losses of $\mathrm{N}$ and base cations rapidly decrease because pools of litter and fine litter gradually adjust to the new litterfall rates. At the end of simulation period the pools of litter and fine litter have decreased bt $57 \%$ and $42 \%$, respectively, relative to the calibration run. Although solute fluxes increase by 20 to $50 \%$ for the major ions, the increase of FWC at 40 and $100 \mathrm{~cm}$ depth is much smaller due to the concurrent increase of water fluxes, which amounts to $32 \%$ at $100 \mathrm{~cm}$ depth. Not considered was decomposition of remaining dead tree roots. Decomposition of fine roots may cause considerable release of $\mathrm{N}$ (Hauhs, 1985). We also did not consider addition of fertilizer after clear-cut, which is a common practice in forestry.

\section{Conclusions}

The dynamics and flexibility of the ILWAS model are adequate to simulate the major features of observed seasonal and annual patterns in soil solution chemistry. Calibration of the ILWAS model to field data is mainly confined to adjustment of 


\section{J. J. M. VAN GRINSVEN ET AL.}

the rate constants of nitrification and gibbsite dissolution. The ILWAS model is a useful tool to evaluate the effects of reduced acid atmospheric deposition and silvicultural mitigation measures on forest soils.

\section{Acknowledgements}

The authors are greatly indebted to the Electric Power Research Institute, in Palo Alto, Calif., USA, in particular to Dr. R. Goldstein, for providing a copy of the ILWAS code.

\section{References}

Alcamo, J., M. Amann, J. P. Hettelingh, M. Holmberg, L. Hordijk, J. Kamäri, L. Kauppi, P. Kauppi, G. Kornai \& A. Mäkelä, 1987. Acidification in Europe: A simulation model for evaluating control strategies. Ambio 16: 232-245.

Arp, P. A., 1983. Modelling the effects of acid precipitation on soil leachates: a simple approach. Ecological modelling 19: 105-117.

Bascomb, C. L., 1964. Rapid method for the determination of cation exchange capacity of calcareous and non-calcareous soils. Journal of the Science of Food and Agriculture 12: 821-823.

Booty, W. G., 1983. Watershed acidification model and the soil acid neutralization capacity concept. PhD-thesis. McMaster University, Hamilton, Ontario, Canada, 194 pp.

Bolt, G. H. (Ed.), 1982. Soil Chemistry. B. Physico-chemical models. Developments in soil science 5 B. Elsevier, Amsterdam, $527 \mathrm{pp}$.

Bloom, P. R. \& D. F. Grigal, 1985. Modeling soil response to acidic deposition in nonsulfate adsorbing soils. Journal of Environmental Quality 14: 489-495.

Breemen, N. van, C. T. Driscoll \& J. Mulder, 1984. Acidic deposition and internal proton sources in acidification of soil and waters. Nature 307: 559-604.

Breemen, N. van, P. H. B. de Visser \& J. J. M. van Grinsven, 1986. Nutrient and proton budgets in four soil-vegetation systems underlain by Pleistocene alluvial deposits. Journal of the Geological Society London 143: 659-666.

Breemen, N. van, J. Mulder \& J. J. M. van Grinsven, 1987. Impacts of acid atmospheric deposition on woodland soils in the Netherlands. II. N-transformations. Soil Science Society of America Journal 51: $1634-1640$

Breemen, N. van, W. Vissser \& Th. Pape (Eds.), 1988. Biogeochemistry of an oak-woodland ecosystem in the Netherlands affected by acid atmospheric deposition. Agricultural Research Reports No. 930. Pudoc, Wageningen, $197 \mathrm{pp}$.

Christophersen, N. \& R. F. Wright, 1981. A model for streamwater chemistry at Birkenes Norway. Water Resources Research 18: 977-996.

Cosby, B. J., R. F. Wright, G. M. Hornberger \& J. N. Galloway, 1985a. Modeling the effects of acid deposition: Assessment of a lumped-parameter model of soil water and streamwater chemistry. Water Resources Research 21: 51-63.

Cosby, B. J., R. F. Wright, G. M. Hornberger \& J. N. Galloway, 1985b. Modeling the effects of acid deposition: Estimation of long-term water quality responses in a small forested catchment. Water Resources Research 21: 1591-1601.

EPRI, 1983. The Integrated Lake-Watershed Acidification Study. Vol. 1. Model principles and application procedures. Report EA-3221. TETRA TECH Inc., Lafayette, California, USA.

EPRI, 1984. The Integrated Lake-Watershed Acidification Study. Vol. 4. Summary of major results. Report EA-3221. TETRA TECH Inc., Lafayette, California, USA.

Feddes, R. A., P. J. Kowalik \& H. Zaradny, 1978. Simulation of field water use and crop yield. Simulation Monographs. Pudoc, Wageningen, 189 pp.

Fendick, E. A. \& R. A. Goldstein, 1986. Response of two Adirondack watersheds to acidic deposition. Water Air and Soil Pollution 33: 43-56. 
Gaines, G. L. \& H. C. Thomas, 1953. Adsorption studies on clay minerals. II. A formulation of the thermodynamics of exchange adsorption. Journal of Chemistry and Physics 21: 714-718.

Goldstein, R. A., S. A. Gherini, C. W. Chen, L. Mak \& R. J. M. Hudson, 1984. Integrated acidification study (ILWAS): A mechanistic ecosystem analysis. Philosophical Transactions of the Royal Society London, Series B 305: 409-425.

Grinsven, J. J. M. van, N. van Breemen, W. H. van Riemsdijk \& J. Mulder, 1987a. The sensitivity of acid forest soils to acid deposition. Proceedings International Symposium on Acidification and water pathways (Bolkesjo), Norwegian National Committee for Hydrology, p. 365-374.

Grinsven, J. J. M., van, N. van Breemen \& J. Mulder, 1987b. Impacts of acid atmospheric deposition on woodland soils in the Netherlands. I. Calculation of hydrologic and chemical budgets. Soil Science Society of America Journal 51: 1629-1634.

Grinsven, J. J. M., van, 1988. Impact of acid atmospheric deposition on soils: Quantification of chemical and hydrologic processes. Doctoral thesis, Wageningen Agricultural University. Pudoc, Wageningen, $215 \mathrm{pp}$.

Hauhs, M., 1985. Wasser- und Stoffhaushalt im Einzugsgebiet der Langen Bramke (Harz). Berichte des Forschungszentrums Waldökosysteme/Waldsterben, Band 17, Göttingen, FRG, 206 pp.

Mulder, J., J. J. M. van Grinsven \& N. van Breemen, 1987. Impacts of acid atmospheric deposition on woodland soils in the Netherlands. III. Aluminum chemistry. Soil Science Society of America Journal 51: 1640-1645.

Reuss, J. O.\& D. W. Johnson, 1985. Effect of soil processes on the acidification of water by acid deposition. Journal of Environmental Quality 14: 26-31.

Reuss, J. O., N. Christophersen \& H. M. Seip, 1986. A critique of models for freshwater and soil acidification. Water Air and Soil Pollution 30: 909-930.

Schnoor, J. L., W. D. Palmer \& G. E. Glass, 1984. Modelling impacts of acid precipitation for northeastern Minnesota. In: J. Schnoor (Ed.), Modelling of total acid precipitation impacts. Acid precipitation series, Vol. 9, p. 155-173. Butterworth, Boston.

Ulrich, B., 1983. Soil acidification and its relation to acid deposition. In: B. Ulrich \& J. Pankrath (Eds.), Effects of accumulation of air pollutants in forest ecosystems. Proceedings Workshop Göttingen, FRG, p. 127-146. D. Reidel Publishing Company, Dordrecht, Netherlands.

Velbel, M. A., 1985. Geochemical mass balances and weathering rates in forested watersheds of the Southern Blue Ridge. American Journal of Science 283: 904-930.

Vries, W. de, 1987. A conceptual model for analysing soil and groundwater acidification on a regional scale. Proceedings International Symposium on Acidification and water pathways (Bolkesjo), Norwegion National Committee for Hydrology, p. 185-194. 